\title{
Perancangan Aplikasi IT Help Desk Menggunakan Platform Node.js Pada Mittasys
}

\author{
Dwi Nurul Huda ${ }^{1}$, Aggry Saputra ${ }^{2}$, Yulinda ${ }^{3}$ \\ 1,2,3 Jurusan Teknik Informatika STT Indonesia Tanjungpinang \\ Jln. Pompa Air No. 28 Tanjungpinang Kepulauan Riau Indonesia \\ 1dwi.nurulhuda@gmail.com
${ }^{2}$ aggrysaputra@gmail.com \\ 3yulindahuangg@gmail.com
}

\begin{abstract}
Mittasys merupakan perusahaan yang bergerak dibidang jasa pemrograman. Perusahaan ini belum memiliki sistem yang mampu menangani masalah hubungan perusahaan dengan pelanggan. Dalam layanan purna jual, perusahaan belum dapat memaksimalkan pelayanan dalam bentuk keluhan ataupun pertanyaan pelanggan. Berdasarkan permasalahan yang ada, penulis membangun sebuah perangkat lunak help desk dalam bentuk aplikasi web. Aplikasi web ini menggunakan waterfall sebagai metode pengembangannya. Perancangan aplikasi ini menggunakan platform Node.js dan menggunakan database Microsoft SQL Server. Dari hasil perancangan perangkat lunak ini diharapkan dapat membantu perusahaaan dalam menanggani setiap pelanggan yang membutuhkan sehingga dapat meningkatkan pelayanan serta menghasilkan keakuratan dalam pencarian data yang dibutuhkan.

Kata kunci : Help Desk, Node.js, Microsoft SQL Server, Keluhan, Pertanyaan.
\end{abstract}

Abstract-Mittasys is a company engaged in programming services. The company have not had a system that is able to handle the company's relationship with customers. In after-sales service, the company has not been able to maximize service of customer complaints or questions. Based on the existing problems, the authors built a help desk software web application. This web application uses waterfall as a method of development. The design of this application uses Node.js platform and uses a Microsoft SQL Server as a database. From the results of software design, it is expected to help the company in handling every customer who needs so as to improve service and produce accuracy in finding the data needed.

Keywords : Complaints, Help Desk, Microsoft SQL Server, Node.js, Questions

\section{PENDAHULUAN}

Inovasi teknologi informasi yang berkembang dengan pesat mempunyai pengaruh besar terhadap sektor bisnis. Pada dunia bisnis yang semakin kompetitif, membuka peluang tumbuhnya berbagai usaha baru yang membuat persaingan semakin ketat. Inovasi yang tidak lagi terbatas pada teknologi tinggi, namun telah menjadi fenomena global yang mempengaruhi semua sektor kehidupan. Bagaimana sebuah informasi mampu menggerakan perdagangan barang melalui transmisi arus informasi dan gagasan seiring dengan meningkatnya jumlah pengguna arus informasi.

Penelusuran informasi terkait kebutuhan setiap individu sangat mengandalkan mesin pencarian yang terhubung dengan internet. Setiap orang bisa menjadi selektif dalam memilih produk ataupun layanan jasa yang ditawarkan oleh sebuah perusahaan. Dalam hal ini untuk mengoptimalkan waktu, memerlukan suatu media yang berisi informasi yang bermanfaat dapat membuatnya mudah memahami produk ataupun layanan dengan cepat agar tidak membuang-buang waktu. Selain itu, juga dapat membangun citra bahwa perusahaan dapat dipercaya dengan informasi yang berhubungan dengan perusahaan dan target pelanggan.

Dewasa ini, perusahaan harus menyadari pentingnya menjaga hubungan dengan pelanggan. Untuk mewujudkan hal tersebut, perusahaan dapat memberikan layanan kepada pelanggan setelah melakukan pembelian produk/jasa atau biasa disebut after sales services. Menjaga kualitas after sales services yang baik berarti dapat membangun dan menjaga hubungan baik jangka panjang dengan pelanggan. Melalui layanan ini, perusahaan menjadi lebih mengetahui dan mempelajari ekspektasi pelanggan.

Setiap perusahaan tentunya akan menyiapkan layanan terbaik untuk setiap pelanggannya. Namun tidak bisa dipungkiri bahwa pelayanan perusahaan tidak luput dalam ketidaksempurnaan. Dalam waktu yang singkat, pelanggan yang terlibat akan menemui ketidakpuasan pada performa layanan perusahaan. Untuk dapat mengevaluasi layanan perusahaan, setiap keluhan ataupun pertanyaan yang diajukan oleh pelanggan harus dapat ditampung dan kemudian ditindaklanjuti.

Mittasys merupakan perusahaan yang bergerak dibidang jasa pemrograman. Perusahaan ini belum memiliki sistem yang mampu menangani masalah hubungan perusahaan dengan pelanggan. Dalam after sales services, perusahaan belum dapat memaksimalkan pelayanan dalam bentuk keluhan ataupun pertanyaan pelanggan. Permasalahan tersebut akan berdampak buruk terhadap loyalitas pelanggan jika tidak segera diberikan solusi.

Berdasarkan permasalahan diatas, maka diusulkan adanya sebuah aplikasi Help Desk yang berfungsi sebagai media komunikasi dua arah antara perusahaan dengan pelanggan. Pelanggan dapat mengajukan keluhan dan pertanyaan tentang program yang digunakan dengan aplikasi ini. Peran lainnya adalah dapat mengarahkan pelanggan untuk berinventasi pada layanan yang ditawarkan untuk membantu bisnis perusahaan mencapai tujuan sehingga menjadi salah satu strategi dalam meningkatan kualitas pelayanan yang baik. 


\section{METODOLOGI PENELITIAN}

\section{A. Metode Pengumpulan Data}

Dalam pelaksanaan kegiatan pengumpulan data yang menjadi dasar dan untuk melengkapi laporan skripsi ini, maka digunakan teknik yang umum dalam kegiatan ilmiah, yaitu:

1. Wawancara (Interview), yaitu kegiatan berupa tanya jawab langsung dengan orang yang berkaitan dengan pengelolaan data keluhan atau pertanyaan. Wawancara ini dilakukan kepada Bapak Victor, S.Kom selaku pimpinan Mittasys.

2. Observasi, pengamatan langsung ke perusahaan dimana dilaksanakan penelitian ini. Metode ini cukup efektif karena langsung meninjau ke bagian yang mengelola data. Observasi dilakukan dengan mengunjungi langsung ke kantor Mittasys di Jl. Ahmad Yani No. 3A Tanjungpinang.

3. Studi Literatur, pengumpulan data yang diambil dari perusahaan yang bersangkutan.

\section{B. Metode Pengembangan Perangkat Lunak}

Dalam hal ini, tahap pengembangan sistem yang digunakan dalam laporan ini adalah menggunakan Metodologi Life Cycle (Waterfall).

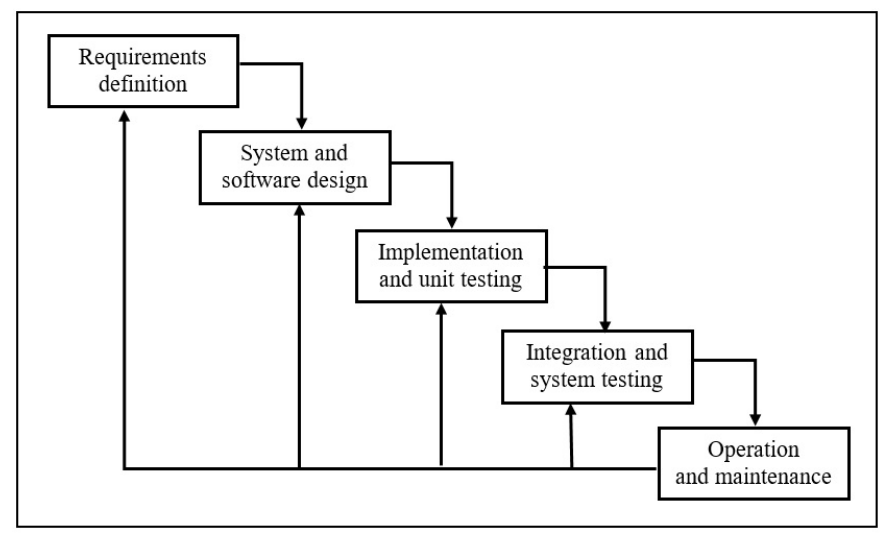

Gambar 1. Metode Pengembangan Waterfall Menurut Somerville (2011)

\section{Requirement Definition}

Tahap ini menguraikan kebutuhan aplikasi yang utuh menjadi komponen-komponen aplikasi untuk mengetahui bagaimana aplikasi dibangun. Informasi ini biasanya dapat diperoleh melalui wawancara, survei atau diskusi. Informasi tersebut dianalisis untuk mendapatkan dokumentasi kebutuhan pengguna untuk digunakan pada tahap selanjutnya.

2. System dan Software Design

Tahap ini merupakan tahap perancangan sistem. Pada tahap ini perancangan difokus pada perancangan struktur data, arsitektur perangkat lunak, representasi interface dan algoritma dalam pembuatan aplikasi. Tahap ini membantu dalam menspesifikasikan kebutuhan hardware dan sistem serta mendefinisikan arsitektur sistem secara keseluruhan.

\section{Implementation and Unit Testing}

Pada tahap ini dilakukan penerjemahan hasil rancangan kedalam bahasa pemrograman komputer. Setelah design selesai diterjemahkan dilakukan pengujian terhadap sistem yang telah dibuat tadi dengan tujuan untuk menemukan kesalahan yang terjadi dan kemudian diperbaiki. Selain itu dalam tahap ini juga dilakukan pemeriksaan terhadap modul yang dibuat, apakah sudah memenuhi fungsi yang diinginkan atau belum.

\section{Integration and System Testing}

Pada tahap integration and system testing ini merupakan tahapan akhir dari pembuatan aplikasi help desk, pada tahap ini sistem sudah bisa digunakan oleh peneliti.

\section{Operation and Maintenance}

Ini merupakan tahap terakhir dalam model waterfall. Software yang sudah jadi dijalankan serta dilakukan pemeliharaan. Pemeliharaan termasuk dalam memperbaiki kesalahan yang tidak ditemukan pada langkah sebelumnya. Perhatikan implementasi unit sistem dan peningkatan jasa sistem sebagai kebutuhan baru.

\section{HASIL DAN PEMBAHASAN}

\section{A. Analisa Sistem yang Berjalan}

Node.js adalah perangkat lunak yang didesain untuk mengembangkan aplikasi berbasis web dan ditulis dalam sintaks bahasa pemrograman JavaScript. Ditulis dengan bahasa JavaScript dan dijalankan pada Windows, Mac OS X, dan Linux tanpa perubahan kode program. Node.js memiliki pustaka peladen HTTP sendiri sehingga memungkinkan untuk menjalankan peladen web tanpa menggunakan program peladen web seperti Apache atau Lighttpd.

Analisis sistem merupakan sebuah istilah yang secara kolektif mendeskripsikan fase-fase awal pengembangan sistem. Analisis sistem adalah teknik pemecahan masalah yang menguraikan bagian-bagian komponen dengan mempelajari, mengidentifikasi dan mengevaluasi berbagai macam masalah atau hambatan yang timbul pada sistem sehingga nantinya bisa dilakukan penanggulangan, perbaikan dan juga pengembangan.

Analisis sistem yang berjalan bertujuan untuk mengetahui lebih jelas bagaimana cara kerja sistem tersebut dan masalah yang dihadapi sistem untuk dapat dijadikan landasan usulan perancangan analisa sistem yang sedang berjalan yang dilakukan berdasarkan urutan kejadian yang ada.

Dibawah ini adalah prosedur pengajuan keluhan/pertanyaan pada pelanggan

1. Pelanggan mengajukan keluhan/pertanyaan.

2. Operator menerima keluhan/pertanyaan dari pelanggan.

3. Operator menganalisa data keluhan/pertanyaan.

4. Operator memberi jawaban dari keluhan/pertanyaan yang diajukan pelanggan. Kemudian jawaban diberikan kepada pelanggan

5. Operator memberikan jawaban kepada pelanggan.

6. Pelanggan menerima jawaban.

7. Operator membuat laporan data keluhan/pertanyaan dari pelanggan.

8. Pimpinan menerima laporan dari operator. 


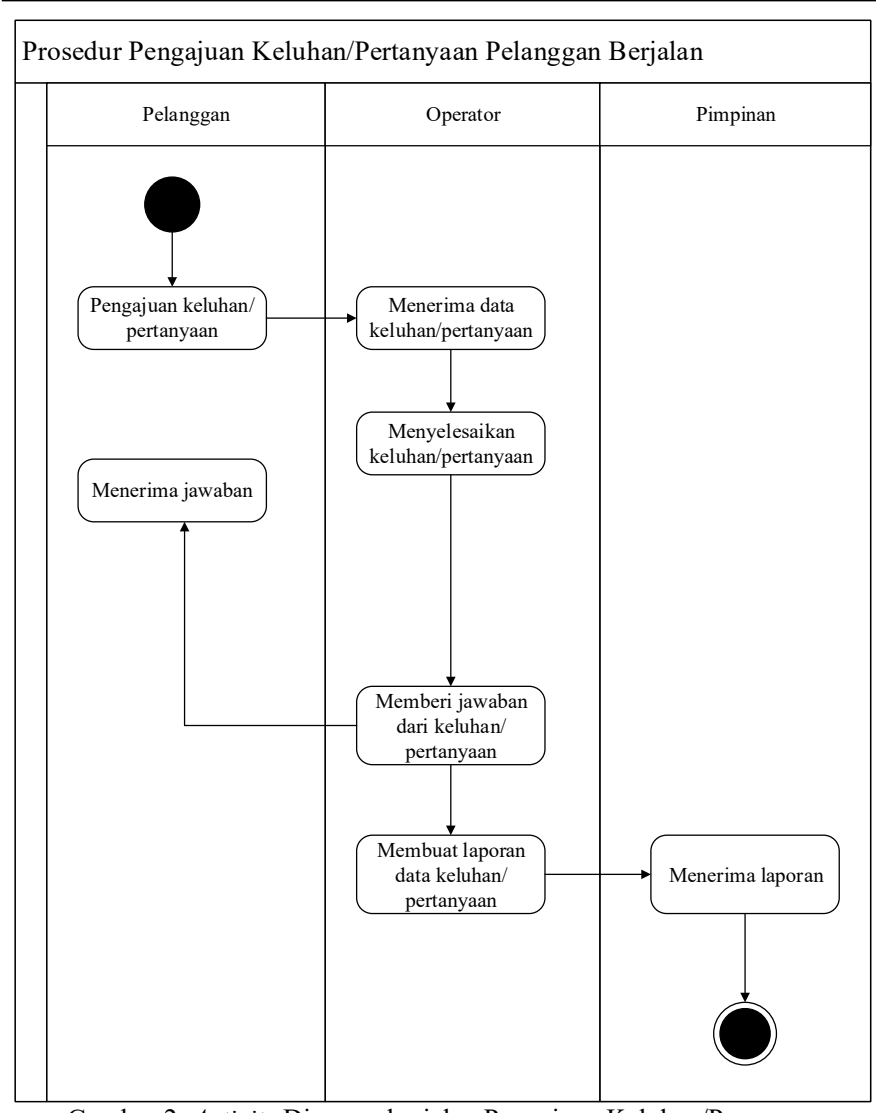

Gambar 2. Activity Diagram berjalan Pengajuan Keluhan/Peranyaan Pelanggan

\section{B. Analisa Kelemahan Sistem}

Terdapat beberapa kelemahan yang ada dalam sistem pada saat ini, yaitu:

1. Pencatatan data (keluhan/pertanyaan) masih dilakukan secara manual.

2. Data yang masuk harus dianalisis dan dibahas terlebih dahulu.

3. Tidak adanya prosedur umum dalam pengajuan keluhan/pertanyaan pelanggan terhadap perusahaan.

4. Data yang dicatat sering hilang sehingga tidak adanya feedback kepada pelanggan.

\section{Analisa Kebutuhan Sistem}

Berdasarkan penelitian yang dilakukan, diketahui bahwa kebutuhan sistem saat ini adalah penyediaan aplikasi yang dapat menangani keluhan/pertanyaan program dan database yang terintegrasi, sehingga akan membantu pelanggan dalam memperoleh informasi dan perbaikan lebih cepat.

\section{Analisa Pengguna}

Analisis pengguna mencirikan siapa saja pengguna dari perangkat lunak yang dispesifikasikan dan apa saja haknya terhadap perangkat lunak tersebut. Pada aplikasi ini ada beberapa pengguna, yaitu:

1. Pelanggan
Pada aplikasi ini pelanggan merupakan orang yang mengakses dan menggunakan aplikasi ini untuk melakukan pengajuan keluhan/pertanyaan.

2. Operator

Operator merupakan orang yang bertanggungjawab mengelola data keluhan/pertanyaan kepada pelanggan dan pimpinan.

3. Pimpinan

Pimpinan memiliki tanggungjawab untuk memantau dan menerima data yang diberikan oleh operator.

\section{E. Use Case Diagram yang diusulkan}

UML menyediakan serangkaian gambar dan diagram yang sangat baik. Beberapa diagram memfokuskan diri pada ketangguhan teori object-oriented dan sebagian lagi memfokuskan pada detail rancangan dan konstruksi. Semuanya dimaksudkan sebagai sarana komunikasi antartim programmer maupun dalam pengguna. Use case diagram menjelaskan interaksi yang terjadi antara aktor dengan sistem. Aktor yang terdapat dalam aplikasi ini adalah: pelanggan, operator dan pimpinan.

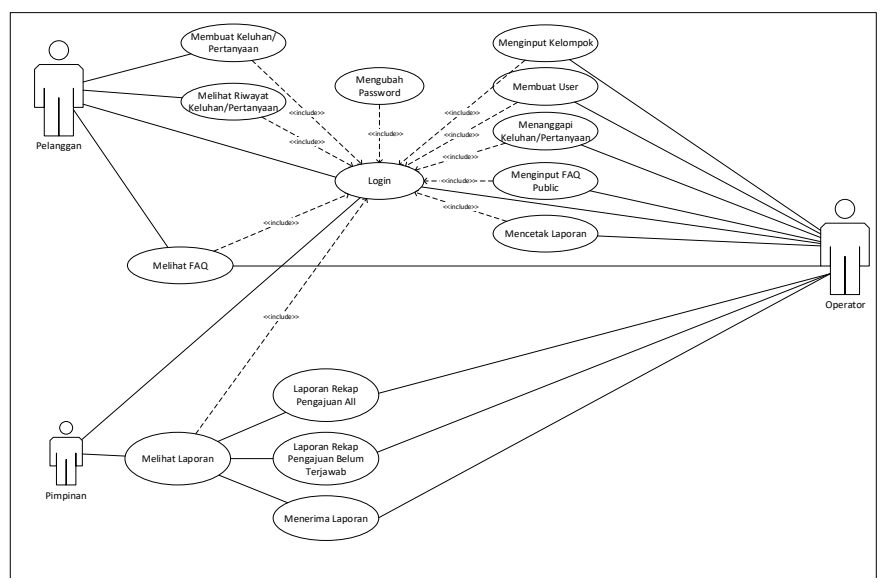

Gambar 3. Use Case Diagram yang diusulkan

Tabel I

Deskripsi Use Case Diagram

\begin{tabular}{|c|c|c|c|}
\hline No & Aktor & Use Case & Keterangan \\
\hline 1 & $\begin{array}{l}\text { Pelanggan, } \\
\text { Operator, } \\
\text { Pimpinan }\end{array}$ & Login & $\begin{array}{l}\text { Setiap aktor harus melakukan } \\
\text { login terlebih dahulu untuk } \\
\text { melakukan entry data pada } \\
\text { aplikasi }\end{array}$ \\
\hline 2 & $\begin{array}{l}\text { Pelanggan, } \\
\text { Operator, } \\
\text { Pimpinan }\end{array}$ & $\begin{array}{l}\text { Mengubah } \\
\text { password }\end{array}$ & $\begin{array}{l}\text { Setiap aktor dapat mengubah } \\
\text { password }\end{array}$ \\
\hline 3 & Pelanggan & $\begin{array}{l}\text { Membuat } \\
\text { Keluhan/ } \\
\text { Pertanyaan }\end{array}$ & $\begin{array}{ll}\text { Pelanggan menginput } & \text { data } \\
\text { keluhan/pertanyaan } & \text { pada } \\
\text { aplikasi } & \end{array}$ \\
\hline 4 & Pelanggan & $\begin{array}{l}\text { Melihat } \\
\text { Riwayat } \\
\text { Keluhan/ } \\
\text { Pertanyaan }\end{array}$ & $\begin{array}{l}\text { Pelanggan melihat riwayat } \\
\text { data keluhan/pertanyaan pada } \\
\text { aplikasi }\end{array}$ \\
\hline 5 & Operator & Membuat User & $\begin{array}{l}\text { Operator menginput user baru } \\
\text { untuk digunakan oleh } \\
\text { pelanggan dalam mengakses }\end{array}$ \\
\hline 6 & Operator & $\begin{array}{l}\text { Menaggapi } \\
\text { Keluhan/ } \\
\text { Pertanyaan }\end{array}$ & $\begin{array}{l}\text { Operator menanggapi } \\
\text { keluhan/ pertanyaan yang } \\
\text { diajukan oleh pelanggan }\end{array}$ \\
\hline 7 & Operator & $\begin{array}{l}\text { Mencetak } \\
\text { Laporan }\end{array}$ & Operator mencetak laporan \\
\hline 8 & Operator & $\begin{array}{l}\text { Membuat } F A Q \\
\text { Public }\end{array}$ & $\begin{array}{l}\text { Operator menginput } F A Q \\
\text { Public yang akan muncul di }\end{array}$ \\
\hline
\end{tabular}


Bangkit Indonesia, Vol. IX, No. 01, Bulan Maret 2020

\begin{tabular}{|c|l|l|l|}
\hline & & & halaman $F A Q$ \\
\hline 9 & Operator & $\begin{array}{l}\text { Menginput } \\
\text { Kelompok }\end{array}$ & $\begin{array}{l}\text { Operator menginput } \\
\text { kelompok untuk digunakan } \\
\text { sebagai data master di form } \\
\text { pengajuan }\end{array}$ \\
\hline 10 & $\begin{array}{l}\text { Operator, } \\
\text { Pelanggan }\end{array}$ & Melihat $F A Q$ & $\begin{array}{l}\text { Operator dan pelanggan dapat } \\
\text { mengakses halaman FAQ } \\
\text { dengan catatan harus login ke } \\
\text { aplikasi terlebih dahulu }\end{array}$ \\
\hline 11 & $\begin{array}{l}\text { Operator, } \\
\text { Pimpinan }\end{array}$ & $\begin{array}{l}\text { Melihat } \\
\text { Laporan }\end{array}$ & $\begin{array}{l}\text { Operator dan Pimpinan dapat } \\
\text { melihat laporan, yang terdiri } \\
\text { dari: laporan rekap pengajuan } \\
\text { all dan laporan rekap } \\
\text { pengajuan belum terjawab }\end{array}$ \\
\hline
\end{tabular}

\section{F. Class Diagram yang diusulkan}

Class Diagram atau diagram kelas merupakan diagram yang menggambarkan struktur sistem dari segi pendefinisian kelas-kelas yang akan dibuat untuk membangun sistem. Diagram kelas memiliki 3 bagian utama, yaitu attribute, operation, dan name. Kelas-kelas yang ada pada struktur sistem harus dapat melakukan fungsi-fungsi sesuai dengan kebutuhan sistem. Berikut adalah gambaran class diagram yang diusulkan:

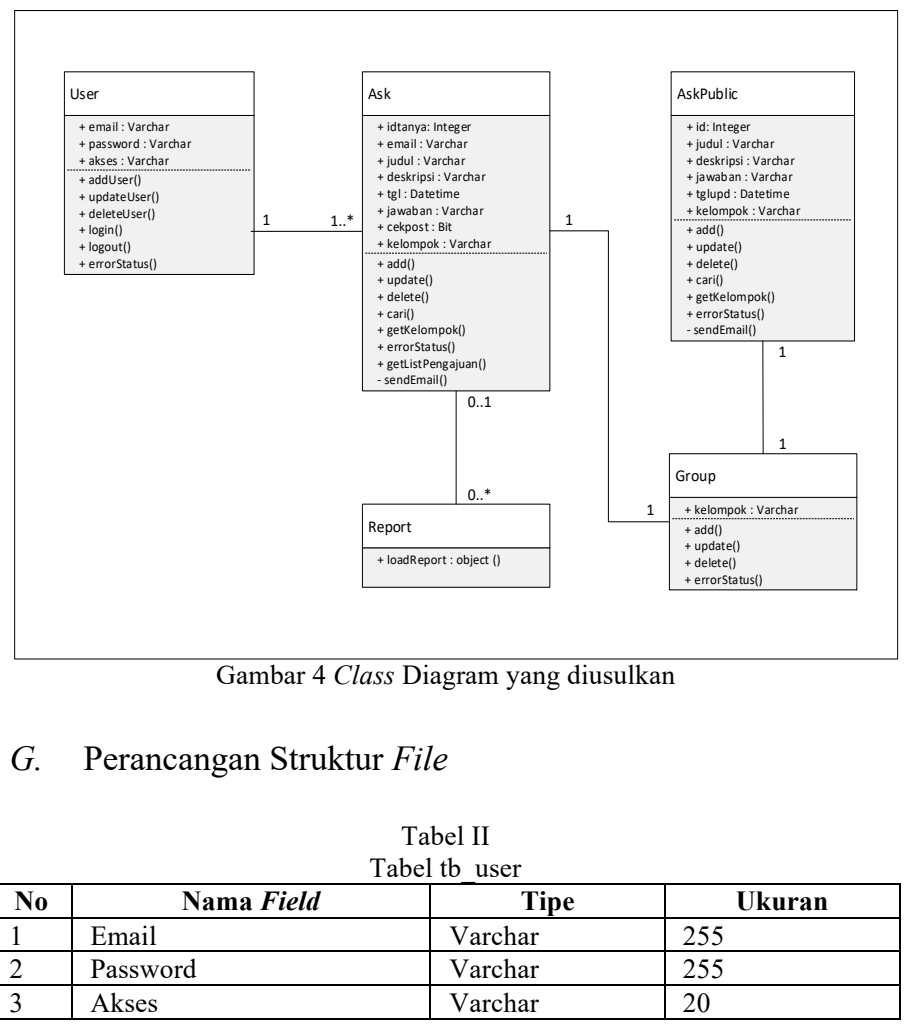

Tabel III

Tabel tb kelompok

\begin{tabular}{|l|l|l|l|}
\hline No & \multicolumn{1}{|c|}{ Nama Field } & Tipe & Ukuran \\
\hline 1 & kelompok & Varchar & 50 \\
\hline
\end{tabular}

Tabel IV

Tabel tb_tanya

\begin{tabular}{|l|l|l|l|}
\hline No & \multicolumn{1}{|c|}{ Nama Field } & \multicolumn{1}{c|}{ Tipe } & Ukuran \\
\hline 1 & idtanya & Int & \\
\hline 2 & email & Varchar & 255 \\
\hline 3 & judul & Varchar & 255 \\
\hline 4 & deskripsi & Varchar & 500 \\
\hline 5 & tgl & Datetime & \\
\hline
\end{tabular}

\begin{tabular}{|l|l|l|l|}
\hline 6 & jawaban & Varchar & 500 \\
\hline 7 & cekpost & Bit & \\
\hline 8 & kelompok & Varchar & 30 \\
\hline
\end{tabular}

Tabel V

Tabel tb tanyapublic

\begin{tabular}{|l|l|l|l|}
\hline No & \multicolumn{1}{|c|}{ Nama Field } & \multicolumn{1}{|c|}{ Tipe } & Ukuran \\
\hline 1 & id & Int & \\
\hline 2 & judul & Varchar & 255 \\
\hline 3 & deskripsi & Varchar & 500 \\
\hline 4 & jawaban & Varchar & 500 \\
\hline 5 & tglupd & Datetime & \\
\hline 6 & kelompok & Varchar & 30 \\
\hline
\end{tabular}

\section{H. Perancangan Struktur Menu}

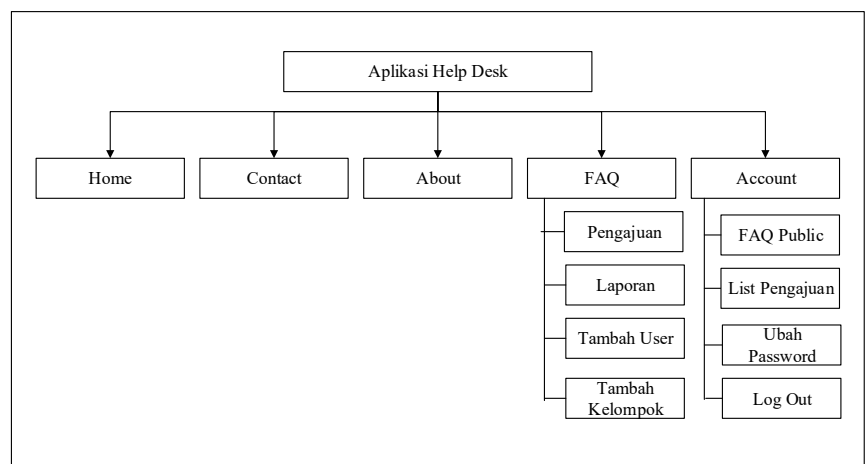

Gambar 5 Perancangan Struktur Menu Operator

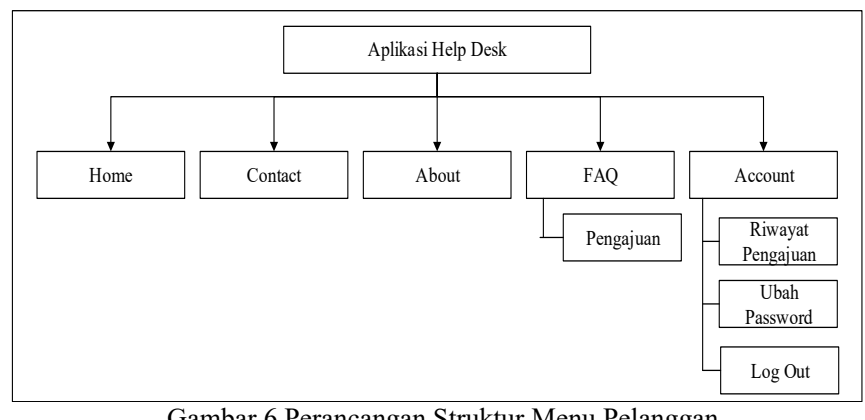

\section{Implementasi Sistem}

1. Halaman Login

Halaman login merupakan halaman yang akan tampil ketika user masuk ke aplikasi.

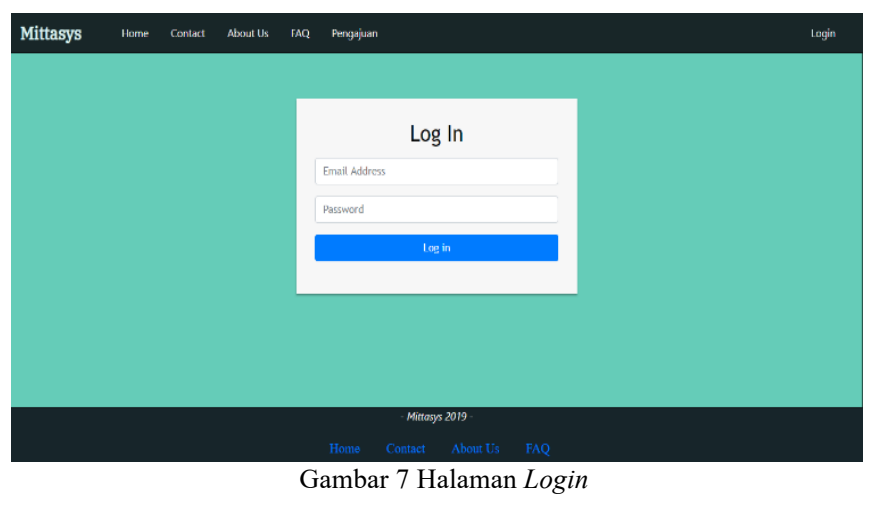

2. Halaman Home

Setelah user berhasil menjalankan proses login maka, tampilan halaman home akan muncul. 


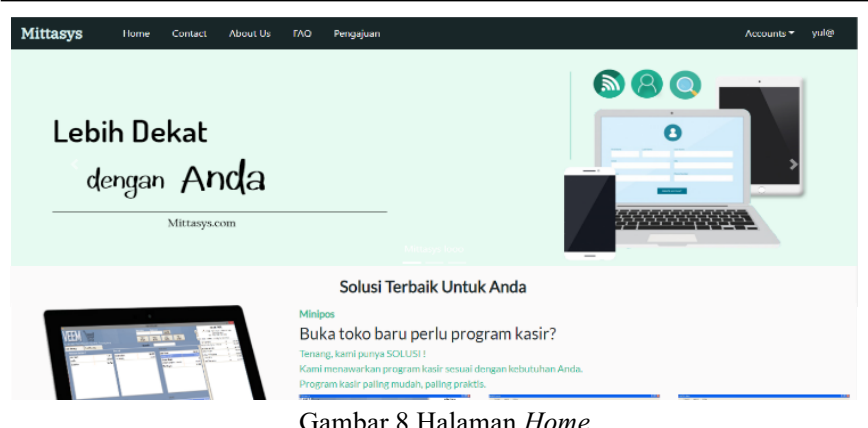

3. Halaman Contact

Halaman contact menampilkan informasi mengenai operasional perusahaan serta form email untuk menanyakan seputar jasa yang lebih lanjut.

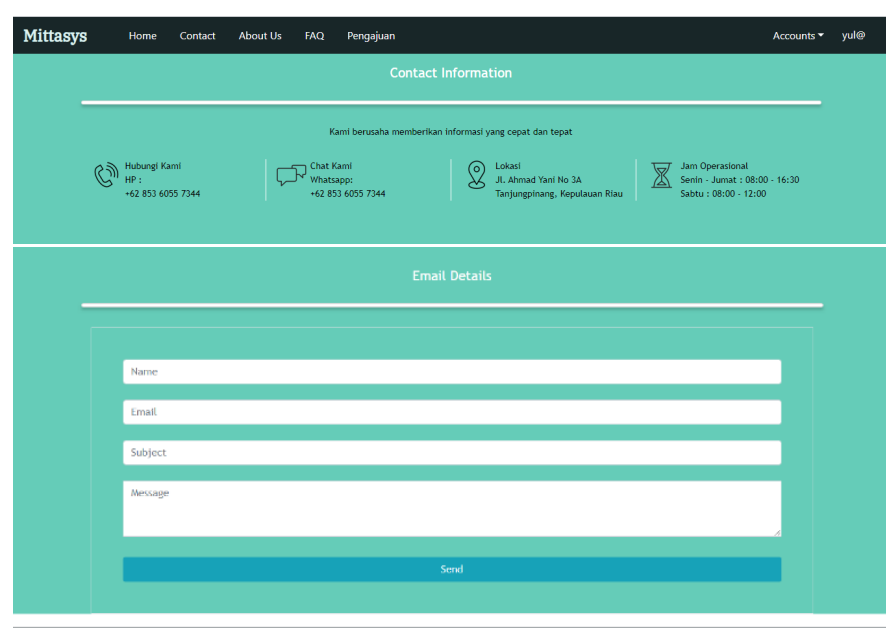

Gambar 9 Halaman Contact

\section{Halaman About}

Halaman About berisikan informasi tentang sejarah perusahaan dan jenis-jenis jasa yang ditawarkan.

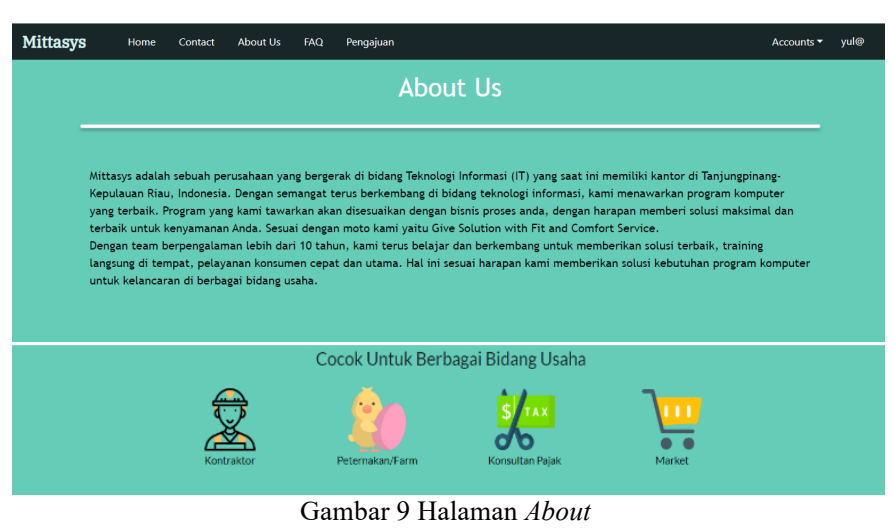

\section{Halaman $F A Q$}

Halaman $F A Q$ berisikan pertanyaan dan jawaban yang sering ditanyakan oleh pelanggan.

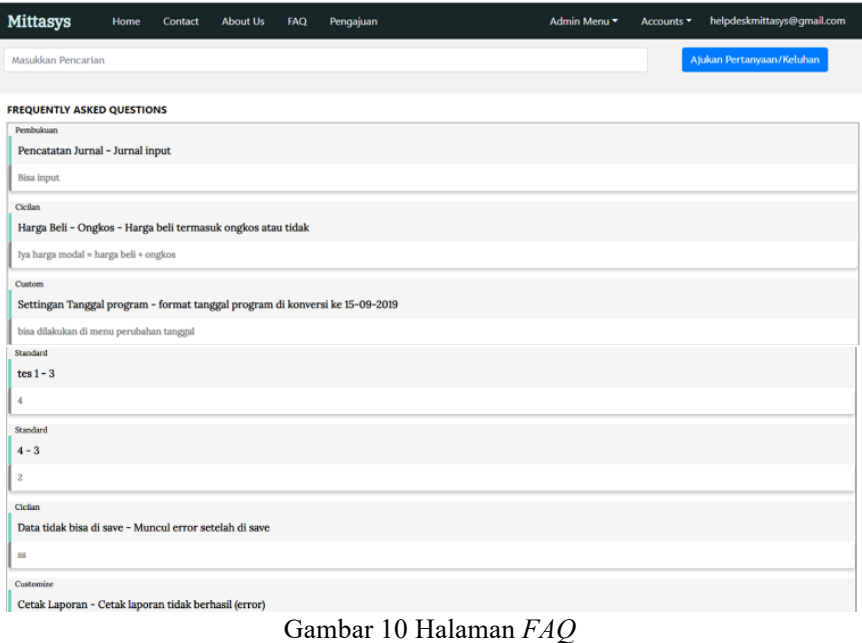

6. Halaman Pengajuan

Halaman pengajuan berfungsi sebagai form untuk pelanggan menginputkan keluhan/pertanyaan pada perusahaan.

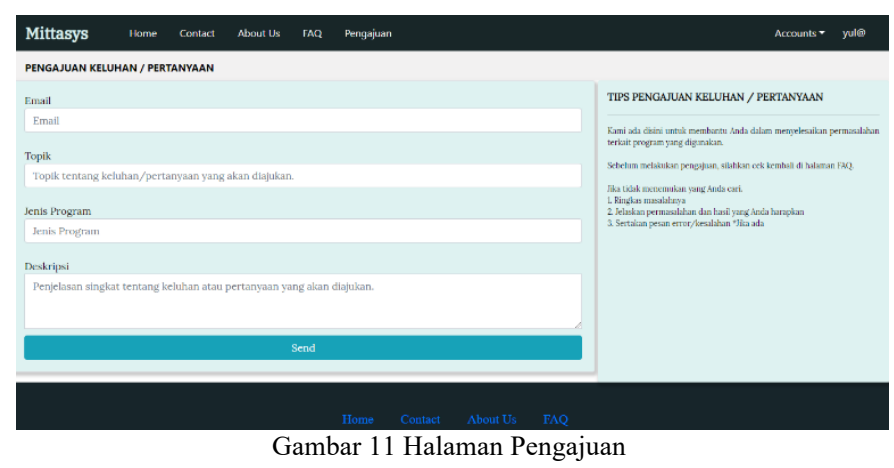

7. Halaman Riwayat Pengajuan

Halaman riwayat pengajuan menampilkan data sesuai dengan email pelanggan yang melakukan pengajuan.

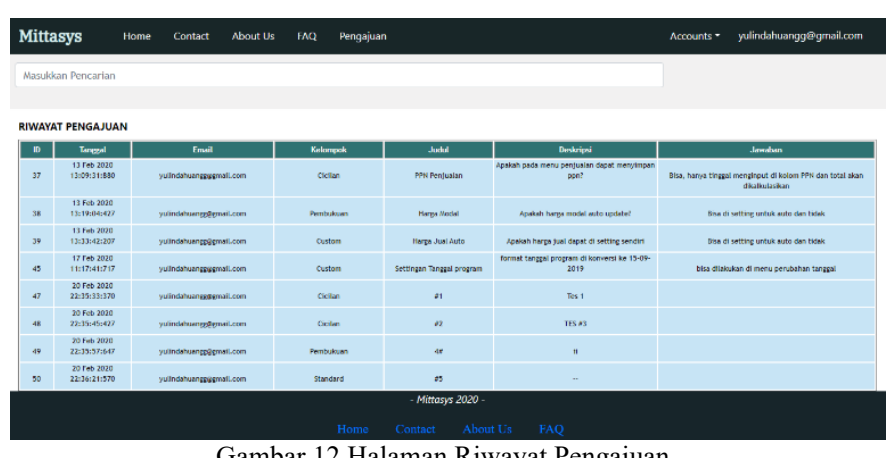

8. Halaman List Pengajuan

Halaman ini merupakan halaman yang diakses oleh operator. Semua data pengajuan pelanggan akan di jawab di menu ini. 


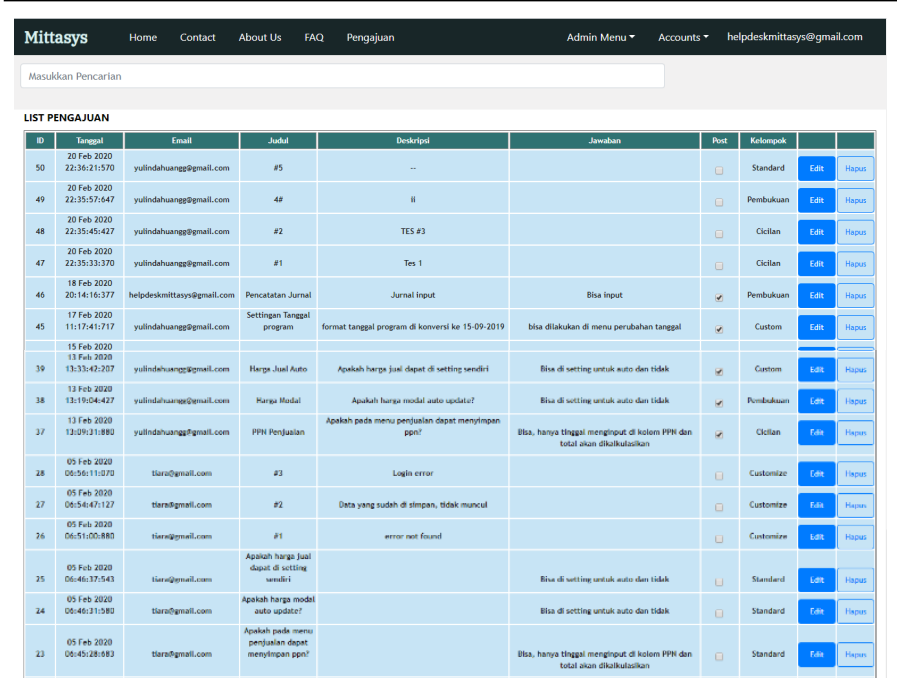

Gambar 13 Halaman List Pengajuan

\section{Halaman FAQ Public}

Halaman ini diinput oleh operator berupa data pertanyaan yang sering ditanyakan oleh pelanggan, dan data yang diinput di menu ini akan muncul di halaman $F A Q$.

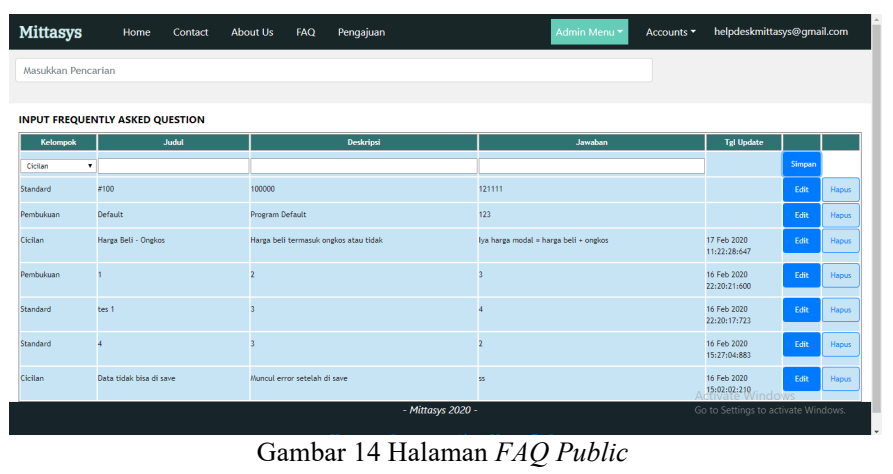

10. Halaman Ubah Password

Halaman ini digunakan oleh user untuk mengubah password.

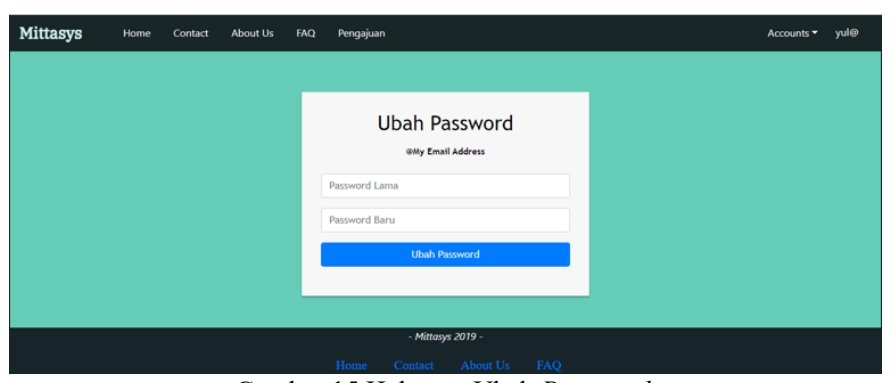

Gambar 15 Halaman Ubah Password

11. Halaman Tambah User

Halaman tambah user digunakan oleh operator untuk menambahkan user baru.

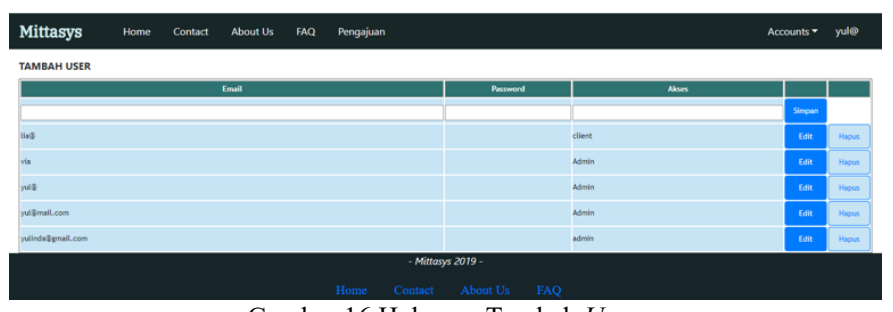

Gambar 16 Halaman Tambah User
12. Halaman Tambah Kelompok

Halaman tambah kelompok adalah master jenis program yang muncul pada halaman pengajuan yang diinputkan oleh operator.

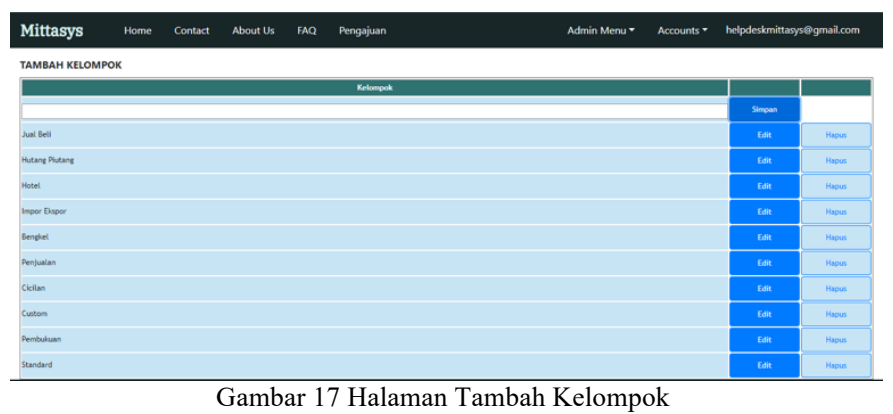

13. Laporan Rekap Pengajuan

Laporan rekap pengajuan adalah laporan akhir untuk melihat data-data pengajuan keluhan.pertanyaan yang diinput oleh pelanggan.

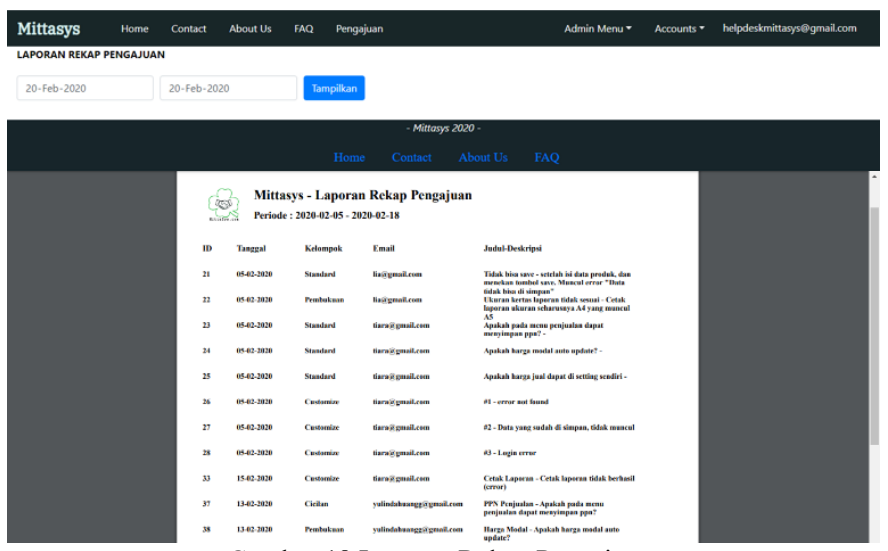

Gambar 18 Laporan Rekap Pengajuan

\section{KESIMPULAN}

Perancangan Aplikasi IT Help Desk Menggunakan Platform Node.Js Pada Mittasys dibuat atas tindak lanjut dari sistem yang sedang berjalan. Aplikasi ini diharapkan dapat membantu perusahaan dalam menangani permasalahan yang ada. Adapun kesimpulan yang dapat di ambil dari pembuatan aplikasi ini adalah: memberikan kemudahan layanan data dalam mengakses informasi dengan menggunakan fitur pencarian data terkait dengan kebutuhan, perancangan aplikasi Help Desk menggunakan platform node.js dapat diakses oleh pelanggan untuk menginput pengajuan keluhan atau pertanyaan. Selain itu, aplikasi dapat menampilkan riwayat data pengajuan sesuai akses login. Operator dan pelanggan dapat dengan mudah mengetahui pengajuan data yang masuk dan yang sudah ditanggapi dengan fitur auto email sebagai notifikasi dalam.proses pengajuan.

\section{REFERENSI} O’Reilly Media. Inc, 2019, USA

Chan Syahrial, Membuat Aplikasi Database dengan PowerBuilder 12.6 dan MySQL, PT. Elex Media Komputindo, 2017, Jakarta. 
Bangkit Indonesia, Vol. IX, No. 01, Bulan Maret 2020

[3] Elisabet Yunaeti dan Rita Irviani, Pengantar Sistem Informasi, CV. ANDI OFFSET, 2017, Yogyakarta

[4] Emma Utami \& Sukrisno, Mengoptimalkan Query pada Microsoft SQL Server, CV. ANDI OFFSET, 2008, Yogyakarta

[5] Hernita P, Panduan Praktis Menguasai Pemrograman Web dengan Javascript, Wahana Komputer, 2010, Yogyakarta

[6] Hutahaean Jeperson, Konsep Sistem Informasi, Deepublish, 2015, Yogyakarta

[7] Muhammad Mushuliddin dan Oktafianto, Analisis dan Perancangan Sistem Informasi Menggunakan Metode Terstruktur dan UML, CV. ANDI OFFSET, 2016, Yogyakarta

[8] Ombro George, Sams Teach Yourself Node.js in 24 Hours, SAMS, 2012, USA

[9] Yudho Yanto \& Ardhi Wijayanto, Yuk Berbisnis dengan Laravel dan Android, PT. Elex Media Komputindo, 2019, Jakarta 